\title{
How to Transition from Cooperations to Cooperatives: A Case Study of the Factors Impacting the Organization of Urban Gardeners in Benin
}

\author{
Donald M. Houessou 1,2,3,*(D), Ben G. J. S. Sonneveld ${ }^{1,4}$, Augustin K. N. Aoudji ${ }^{2}$, \\ Frejus S. Thoto ${ }^{2,3}$, Smith A. R. Dossou ${ }^{2}{ }^{\circ}$, Denyse J. R. M. Snelder ${ }^{5}$, Anselme A. Adegbidi ${ }^{2}$ and \\ Tjard De Cock Buning 1 (D) \\ 1 Athena Institute, Vrije Universiteit Amsterdam, De Boelelaan 1085, 1081 HV Amsterdam, The Netherlands \\ 2 Laboratoire d'Etude sur la Pauvreté et la Performance de l'Agriculture (LEPPA), \\ Faculty of Agricultural Sciences, University of Abomey-Calavi, 03 BP 2819 R.P. Cotonou, Benin \\ 3 Centre d'Actions pour 1'Environnement et le Développement Durable, BP 660 Abomey-Calavi, Benin \\ 4 Amsterdam Centre for World Food Studies, De Boelelaan 1085, 1081 HV Amsterdam, The Netherlands \\ 5 Centre for International Cooperation, Vrije Universiteit Amsterdam, De Boelelaan 1105, \\ 1081 HV Amsterdam, The Netherlands \\ * Correspondence: donaldhouessou@gmail.com or m.d.houessou@vu.nl; Tel.: +2-29-9609-1680
}

Received: 21 June 2019; Accepted: 18 August 2019; Published: 21 August 2019

check for updates

\begin{abstract}
Urban gardening offers a viable option to improve diet diversity for the urban poor. Yet, its success rate is particularly dependent on the managerial capacities of urban gardeners to coordinate and organize collective actions for the successful exploitation of the gardens. The calls from governments to organize cooperative structures among farmers seem justified and merits a high priority on agricultural policy agendas. Although principles of cooperative structures exist, there is no blueprint available that indicates how to start a gardeners' cooperation. Moreover, these collaborations need to ally with and build on existing social structures of the urban gardeners involved. Our research can contribute to this alignment process by exploring and comparing international standards of prevailing organizations and their functioning among 261 gardeners in two cities in Benin. We found that a vast majority of urban gardeners are members of a cooperation. Nevertheless, their membership is largely titular because gardeners mostly behave semi-autonomously and few decisions are taken collectively. The obvious economic advantages of leveraging bargaining power, reducing transaction costs, and increasing possibilities for loans are seriously underutilized. We suggest that capacity building can help to develop cooperation among urban gardeners to reach their full potential which, congruently, should also improve the livelihoods of the urban poor.
\end{abstract}

Keywords: collective action; management; functioning; cooperative longevity; allotment gardens; cities; urban agriculture; Africa

\section{Introduction}

Urban agriculture can be defined as the utilization of small areas within and around cities for growing crops, raising small livestock, and processing food-related products, alone or in combination, for own-consumption or sale [1,2]. Urban agriculture can take different forms depending on the characteristics (types of actors, location, products, technology, types of economic activities, and degree of market orientation) used for the classification, as nicely developed by Dubelling et al. [3]. For instance, depending on the location, urban agriculture may take various forms such as home gardening, park gardening, and allotment gardening, which is the focus of our study. 
Urban allotment gardens, herein referred to as urban gardening, may increase the dietary diversity of the urban poor by providing ready access to vegetables, fruits, and some small livestock. Yet, the degree and extent to which urban gardeners pool their resources, protect their interests, and organize their collaboration are vital to the successful and efficient functioning of urban gardening [4]. Indeed, in many developing countries, a considerable proportion of farmers rely on agricultural cooperatives to govern their market transactions [5]. Farmers set up cooperatives to promote, safeguard, and strengthen their oftentimes weak marketing position in society [6]. By joining forces and becoming members and users of the services provided by their collective organization, farmers intend to increase the efficiency of their crop and livestock production. These cooperatives manifest themselves in particular contexts, usually in response to certain stimuli, for example, market failures, and they aim to achieve specific objectives and goals as defined by the membership [7]. In that sense, cooperatives may increase the market's share, the sale, the bargaining power, and the market information for their members. In the same vein, cooperatives may also reduce external shocks such as the hold-up problem, which may be induced by competitive markets, and the transaction costs in general. The cooperative model in agriculture can, therefore, empower producers and improve their quality of life and enhance their economic viability through social organization [8]. The cooperative model provides a framework that offers scale to farmers, which brings associated advantages that would not be achieved if acting individually [9-12].

Evidence shows that the two main purposes of agricultural cooperatives in developing countries are to enhance the market participation of smallholder farmers and improve their bargaining positions through leveraging collective action [13-16]. Furthermore, Fanasch and Frick [17] listed three advantages of cooperatives as follows: economies of scale, reduction of transaction costs, and avoidance of hold-up situations. First, due to its size, a cooperative can realize economies of scale because the members of the cooperatives can pool resources, which allows the cooperative to offer access to otherwise unavailable technology, as well as information and consulting services [18]. The shared resources can be of any kind-such as technical equipment or buildings, reputation, or bargaining power [17] —and the services offered by the cooperative can be typically cheaper for small farmers who, individually, would be incapable of affording these services [19]. Second, cooperatives can significantly reduce their individual members' transaction costs [20,21], allowing more efficient bargaining when purchasing and selling commodities or services [22,23]. Because cooperatives often purchase large quantities of raw materials or intermediate products, they are in a better bargaining position than individuals and, in turn, can often negotiate considerable quantity discounts [17]. As a result of this advantage, the cooperative can increase profit margins for members by selling their products at higher prices and yielding higher margins because of lower transaction costs [24]. Cakir and Balagtas [25] showed that agricultural cooperatives in the United States were able to increase the price of milk above marginal costs. Third, membership in a cooperative helps to avoid hold-up situations that arise when a party exercises market power and distorts the market prices [26]. Indeed, members of a cooperative can be assured that they will be paid the ex-ante agreed price [17].

In African countries, attempts by governments to organize farmers into cooperatives have increased in recent years. For instance, in Ethiopia, agricultural cooperatives are accepted policy instruments for collective input purchase and output marketization for smallholder farmers and account for about $90 \%$ of modern input supply and more than $10 \%$ of the marketing of agricultural surplus in the country $[27,28]$. In South Africa, the government signed into law, on August 2005, a new act to promote the use of cooperatives as organizations that could help enhance the development of small-scale farmers and other communities in the country [8]. In Namibia, the government promotes the use of cooperatives as business organizations that can help in the development of farmers through the National Cooperative Policy (2012) and also assists in developing entrepreneurial, organizational, and managerial skills for farmers who are members of cooperatives [29]. This is also the case in the Republic of Benin, hereafter referred to as Benin, which recently (December 2010) signed into law, in collaboration with other member states, the Ninth Uniform Act of the Organization 
for the Harmonization of Business Law in Africa (entitled the Uniform Act Relating to Cooperative Enterprises, applicable to all economic sectors) [30].

Despite this, compliance with the legislation among farmers in Benin is very weak due to three reasons [31]. First, the legislation does not apply solely to agriculture, and therefore some of its provisions are difficult to apply to the reality of the sector. For example, the legislation is quite strict in terms of its requirements for the management of cooperative enterprises especially about establishing a board of directors, which can only be fully applied to a tiny number of producer organizations. Second, little consultation with farmers was carried out during the drafting stage of the legislation to consider their specific challenges, such as organizing a volunteer group to promote collective actions. Third and finally, there was a lack of understanding of the text by extension officers in popularizing the legislation and supporting farmers during the registration and implementation process. Solutions to address these challenges are possible (e.g., adaptability of conditions to agriculture, technical and institutional support, capacity building programs) but require the involvement of farmers, civil society, extension officers, technical and financial partners, and most importantly, the government [31]. However, this is not an easy task. Following Gning and Larue [31], support for farmers' cooperations require information on how their members are currently organized and function within their organizations. Learning from Ostrom [32], used a broad conception of cooperation for whenever groups try to gain joint benefits through collective action, we define cooperations in our study as not-institutionalized groups that join forces in a project, i.e., to cooperate as an act in itself. The collected information is required as a first step in supporting farmers to promote an incremental transition from current practices toward a cooperative enterprise rather than imposing an abrupt change to their current organizational operation.

Our research addresses the knowledge gap on how urban gardeners in Benin are organized and cooperate. We, therefore, aim to explore various aspects that might explain successes or failures in the organization and functioning of cooperative structures that prevail in urban allotment gardens. Our study stems from local knowledge on groups' management to suggest optimal ways for collective actions in the transition from cooperations to cooperatives that can inform policymaking. We, therefore, conducted a survey among 261 experienced gardeners in two cities in Benin to elicit information on the organization of cooperations' structure. This research compares our findings with international standards on cooperative organizations and the results of a literature survey to suggest practical solutions that improve cooperation among gardeners.

The set of cooperatives principles of the International Cooperative Alliance (ICA) provides us with a useful instrument to judge the level of organization of gardeners' cooperatives. These principles are guidelines by which cooperatives put their values into practice in meeting their members' economic, social, cultural, and environmental needs. They are universal and interdependent, and their application may vary, not just across cultures and traditions but also with the size, stage of development, and focus of the cooperatives [33]. The seven principles are named as follows, respectively: voluntary and open membership; democratic member control; member economic participation; autonomy and independence; education, training, and information; cooperation among cooperatives; and concern for community [33]. In the first principle, cooperatives are voluntary organizations, open to all persons able to use their services and willing to accept the responsibilities of membership, without gender, social, racial, political, or religious discrimination. In the second principle, cooperatives are democratic organizations controlled by their members, who actively participate in setting their policies and making decisions. Men and women serving as elected representatives are accountable to the membership. In primary cooperatives, members have equal voting rights (one member, one vote), and cooperatives at other levels are also organized in a democratic manner. In the third principle, members contribute equitably to, and democratically control, the capital of their cooperative. At least some part of that capital is usually the common property of the cooperative. Members usually receive limited compensation, if any, on capital subscribed as a condition of membership. Members allocate surpluses for any or all of the following purposes: developing their cooperative, possibly by setting up reserves, 
at least part of which would be indivisible; benefiting members in proportion to their transactions within the cooperative; and supporting other activities approved by the membership. The fourth principle states that cooperatives are autonomous, self-help organizations controlled by their members. If they enter into agreements with other organizations, including governments, or raise capital from external sources, they do so on terms that ensure democratic control by their members and maintain their cooperative autonomy. In the fifth principle, cooperatives provide education and training for their members, elected representatives, managers, and employees so they can contribute effectively to the development of their cooperatives. Cooperatives inform the general public-particularly young people and opinion leaders-about the nature and benefits of cooperation. The sixth principle states that cooperatives serve their members most effectively and strengthen the cooperative movement by working together through local, national, regional, and international structures. In the last principle, cooperatives work for the sustainable development of their communities through policies approved by their members.

In addition, we answer the question of how cooperations of gardeners function by comparing survey results with the salient details found in the literature. Finally, our research builds on the work of Cook [34] about the life cycle theory of agricultural cooperatives to better inform policies on the current stage of evolution of cooperations and supportive measures. Cook [34] proposed a dynamic, path-dependent five-stage model to assess the evolution of cooperatives. These five stages are named as follows: economic justification; organizational design; growth, glory, and heterogeneity; recognition and introspection; and choice $[16,35,36]$. Stage one justifies the economic reasons for producer collective action: (a) attempts to improve low prices or to lower input prices caused by excess supply/shortage of the respective commodity, or (b) low/high prices caused by monopolistic/monopsonistic behavior emanating from market failure. In stage two, cooperatives that formed to ameliorate low prices because of excess supplies/demand historically were ineffective because of their inability to control or affect supply/demand without government support. Consequently, the agricultural cooperatives that survived have their roots in attempting to ameliorate market failures. In stage three, the surviving cooperatives, after succeeding to correct for market failures, modify their strategies. By trying to minimize their costs and invest in capital-intensive industries, in order to be competitive and thus better serve their members, cooperatives are faced with emerging and vaguely defined property rights challenges. In stage four, cooperative decision-makers become aware of the property rights constraints and conclude that they have three options: (a) exit; (b) continue, but modify their current organizational structure; or (c) radical restructuring. During stage five, the cooperative leadership chooses between the above options.

This paper is organized as follows. Section 2 reports on the methods used for this study, concerning the selection of study areas, sampling, survey implementation, and data processing. Section 3 discusses the results in the following categories: organization among urban gardeners, management, responsibility for common tasks, acquisition of urban garden areas, purchasing inputs, transport and sale of products, access to credit, and validation. Section 4 confronts the survey findings with the principles of ICA, discusses the functioning of cooperations by comparing survey findings and the literature and, finally, provides policy recommendations after analyzing the stages of development according to Cook's life cycle theory. Section 5 concludes and indicates the future implications of the research.

\section{Materials and Methods}

\subsection{Study Areas}

We conducted the study in two cities in southern Benin: Cotonou and Porto-Novo. The two cities were selected because they were the most densely populated urban areas in the country [37]. Cotonou is the seat of government, whereas Porto-Novo is the capital city. Cotonou is Benin's most populous city and the country's economic center. The city is located between the Atlantic Ocean and 
Lake Nokoue in the south-eastern part of the country. The city hosts a free trade zone in the interior that allows landlocked Saharan states to exchange goods [38]. Porto-Novo is located in an inlet on the Gulf of Guinea and is also a thriving center of commerce, especially with Nigeria [38].

\subsection{Sampling}

We decided to work with urban allotment gardens where local agencies of the Ministry of Agriculture provide their extension services because this would make it easier to collect information on the population of our study. We found that the Ministry provides agricultural advice to 29 allotment gardens in the two cities, and we included all gardens (Figure 1) in our study.

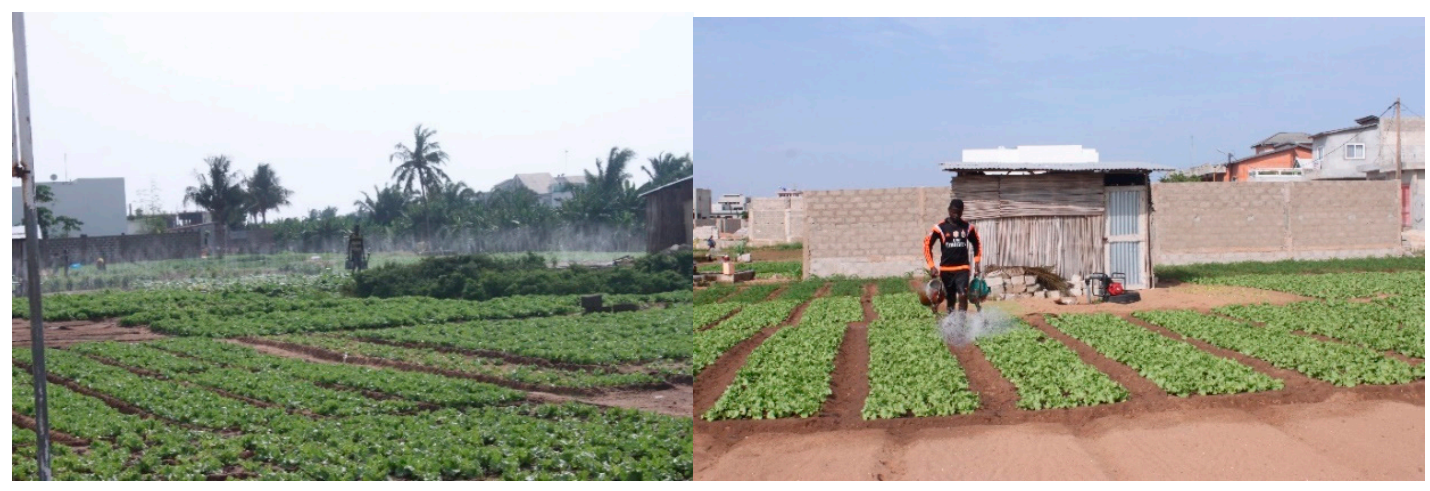

Figure 1. An urban garden with an irrigation system (left) and a gardener watering the plots (right).

The allotment gardens had a total of 828 urban gardeners, and we used the formula of Yamane [39] $\left(n=N / 1+N(e)^{2}\right)$ to calculate the sample size and obtained 270 respondents. However, because the sample size exceeded 5\% of the population, Cochran's [40] correction formula $\left(n^{\prime}=n /(1+n / N)\right)$ was used to calculate the final sample size which, gave 204 respondents. Afterward, we applied a two-stage stratified random sampling. First, we determined the share of urban gardeners over the two cities with respect to the total number of urban gardeners. Next, we determined the share of urban gardeners over the allotment gardens per city. Multiplication of both shares with the desired number of urban gardeners to be interviewed gave the number of randomly selected gardeners per allotment garden (Table 1). We also chose to randomly interview at least three members per garden and adjusted the sample size accordingly. We obtained 261 gardeners for the survey in total. The selection of respondents was conducted at random with replacements, if required (i.e., in case a participant was not available, another person was randomly chosen) and with the possibility of repeat.

Table 1. Survey sample.

\begin{tabular}{ccccc}
\hline \multirow{2}{*}{ City } & \multirow{2}{*}{ Number of Gardens } & Study Population & \multicolumn{2}{c}{ Study Sample } \\
\cline { 4 - 5 } & 9 & & Count & Percent \\
\hline Cotonou & 20 & 209 & 189 & 72.41 \\
Porto-Novo & 29 & 828 & 72 & 27.59 \\
\hline Total & & & 261 & 100.00 \\
\hline
\end{tabular}

\subsection{Survey Implementation}

We designed the survey in spreadsheet format with validated lists in scroll-down menus as a standard response with dedicated fields for open answers. Inserted data were stored in a vector format that facilitated further processing. We provided the enumerators with survey instructions about using the hard copy of the questionnaire in the field, filling in the digital questionnaire to store data, applying sampling schemes to choose respondents randomly in the field, and approaching the gardeners by gaining their trust and dealing tactfully with controversial answers. We also wrote a 
storyline to introduce the purpose of the survey, its processing and translation into policy measures, and the follow-up of the research through active participation of the gardeners.

\subsection{Data Processing and Analysis}

We processed the data using Minitab 14 in three steps. First, the collated output was read as a vector and labeled according to the questions' codes. Second, categorical answers were harmonized in standard formats and presented as frequencies, whereas numerical answers were processed and presented as a mean and quartiles. To disclose specific experiences among gardeners, we created the annex tables (Appendix A) and referred to them in the results section to account for additional responses that provided further explanations to the main responses; further details are in a working document [41]. After data processing, we organized a focus group discussion with 22 participants: 20 male and female gardeners and two experts from local agencies of the Ministry of Agriculture of the two cities. The aim was to discuss and verify the main findings of the study.

Concerning the analysis of our findings, we compared the organizational structures of the cooperations of urban gardeners to the prevailing principles of ICA [33], which are considered as a guide for successful cooperatives [42] if followed with fidelity. The functioning of the organizations was evaluated against various sources derived from literature on organization and management science. In this paper, we related the life cycle theory of Cook $[34,36]$ to the current situation of cooperations to interpret the stage of their evolution and formulate interventions for their long-term functioning.

\section{Results}

\subsection{Organization among Gardeners}

A majority (89 percent) of respondents indicated that they were organized in a group (Table 2). Of those, 94 percent belonged to a formal cooperation (Table A1). Among respondents, 50 percent of the organized groups had 42 members or fewer, with, on average, 37 men or fewer and 5 women or fewer. Three-quarters (75 percent) of the organized groups had 60 members or fewer, with 54 men or fewer and 10 women or fewer (Table A2).

Table 2. Organization among gardeners.

\begin{tabular}{|c|c|c|}
\hline \multicolumn{3}{|c|}{ D1. Are You Organized in a Group? } \\
\hline D1 & Count & Percent \\
\hline No & 29 & 11.11 \\
\hline Yes & 232 & 88.89 \\
\hline \multicolumn{3}{|c|}{$N=261$} \\
\hline
\end{tabular}

Of the respondents, 76 percent of the group members paid a membership fee regularly (Table A3). The frequency of the fee varied per group, but the three most prevalent periods were monthly (31 percent), yearly (26 percent), and weekly (20 percent) (Table A4). On average, 75 percent of gardeners paid XOF 2500 (3.8 euros) and XOF 500 (0.76 euro) per month and week, respectively, for the membership fee, whereas the reported yearly fee was unclear (Table A5). Among the purposes associated with the membership fee, two main reasons were the purchase of fertilizer (43 percent) and the purchase of seeds (36 percent) (Tables A6 and A7). These figures show a sense of organization among most gardeners who were members of cooperations and paid a regular membership fee to the organization.

\subsection{Authority of the Management Board}

Almost all members (99 percent) organized in a group indicated that the organization had a management committee (Table 3), of which 50 percent elected the committee, whereas the other 
50 percent showed a diverse leadership choice-formed by first occupants ( 9 percent), elders (17 percent), and others (74 percent)—such as by management ability, honesty, or simple designation (Tables A8-A10).

Table 3. Existence of a management committee.

\begin{tabular}{ccc}
\hline \multicolumn{2}{c}{ D1.4 Does the Organization Have a Management Committee? } \\
\hline D14 & Count & Percent \\
\hline No & 2 & 0.86 \\
Yes & 229 & 98.71 \\
$\mathrm{Na}$ & 1 & 0.43 \\
\hline \multicolumn{3}{c}{} \\
\hline
\end{tabular}

In any case, 76 percent of those recognizing the existence of management indicated that the committee had a term of office (Table A11). Ninety-six percent of those organized in a group acknowledge the authority of the leader or board (Tables A12 and A13). We may conclude that gardeners widely recognize the authority of the management team.

\subsection{Responsibility for Common Tasks}

Of members who were organized in a group, 95 percent indicated that they shared the responsibility for common tasks (site surveillance, participation in meetings, and offering labor help to other members) (Table 4), but in practice, only 84 percent complied with the assigned tasks (Table A14).

Table 4. Share of the responsibility for common tasks.

D1.6 Do You Share the Responsibility for Common Tasks (Site Surveillance, Participation in Meetings, Offering Help to Other Members, etc.)?

\begin{tabular}{ccc}
\hline D16 & Count & Percent \\
\hline No & 8 & 3.45 \\
Yes & 220 & 94.83 \\
Na & 4 & 1.72 \\
\hline & $N=232$ & \\
\hline
\end{tabular}

To better understand the management aspect, gardeners were asked whether the groups had a constitution and an agreement on the rules of ownership. A majority- 98 percent-indicated that their organization had a constitution, but only 44 percent had an agreement on the rules of ownership (individual plots or communal lands/fair share of profits) (Tables A15 and A16) The figures show that, possibly, cooperations avail of a legal framework and arrange to a certain extent their land tenure.

\subsection{Means of Acquisition of the Gardening Area}

Fifty percent of gardeners had a free access contract (they did not pay a contribution for their participation) on the land where they garden, whereas 39 percent had free access without a contract. In addition, 7 percent leased the area, 3 percent obtained the area through donation, and 2 percent indicated that the area belonged to a member's parent or a private person (Table 5). Gardeners with a free access contract obtained it from public institutions (70 percent), private persons (12 percent), private institutions (11 percent), or others (4 percent) (Tables A20 and A21). 
Table 5. Means of acquisition of the gardening area.

\begin{tabular}{ccc}
\hline \multicolumn{3}{c}{ D2. How Did You Get the Area Where You Garden? } \\
\hline D2 & Count & Percent \\
\hline Lease contract & 17 & 6.51 \\
Free access contract & 130 & 49.81 \\
Donation & 7 & 2.68 \\
Belonged to a member's parent & 3 & 1.15 \\
Belonged to a private person & 1 & 0.38 \\
Free access without contract & 101 & 38.70 \\
Na & 2 & 0.76 \\
\hline \multicolumn{3}{c}{$N=261$} \\
\hline
\end{tabular}

The contract was written or verbal for 39 percent, but many respondents did not know the duration of the contract (Tables A22 and A23). Those with a lease contract mostly had a written or verbal contract; 50 percent paid XOF 4000 (6.10 euros) or less, and 75 percent paid XOF 7000 (10.67 euros) or less per month (Tables A17 and A19). The duration of the contract was two years or less for 50 percent and five years or less for 75 percent (Table A18). In all cases, gardeners had been working on the area for 14 years on average, with 50 percent working for 10 years or less and 75 percent for 20 years or less (Table A24). Although the free access contract was not clearly defined in most cases, gardeners had been working continuously for more than 10 years. We may conclude that gardeners probably negotiate well to obtain plots for their activity.

\subsection{Methods of Purchasing Inputs}

More than three-quarters-77 percent-of gardeners purchased their own inputs individually, whereas 20 percent had a joint purchase arrangement, and 2 percent employed both methods (Table 6). Of those who jointly purchased their inputs, 89 percent were satisfied with the organization, whereas the remainder (11 percent) cited two reasons for their dissatisfaction-the quantity did not suit their needs and they did not trust the management team or other members (Tables A25 and A26).

Table 6. Methods of purchase of inputs.

\begin{tabular}{|c|c|c|}
\hline \multicolumn{3}{|c|}{ D3. How Do You Purchase the Seeds and Fertilizer? } \\
\hline & Count & Percent \\
\hline Joint purchase & 53 & 20.31 \\
\hline Individual purchase & 200 & 76.63 \\
\hline Others (both methods) & 5 & 1.92 \\
\hline $\mathrm{Na}$ & 3 & 1.15 \\
\hline \multicolumn{3}{|c|}{$N=261$} \\
\hline
\end{tabular}

Of those who individually purchased their inputs, 73 percent were satisfied with this method, whereas the rest were willing to make a joint purchase (Tables A27 and A28). We may conclude that most gardeners currently purchase their inputs individually.

\subsection{Methods of Transport of Produce}

Depending on sale opportunities, gardeners employed different methods to organize the transport of their produce to clients (retailers, hotels, restaurants). For example, 67 percent of gardeners sold their production on farm, whereas 26 percent used their own transport, 2 percent leased a taxi (motorbike or car), and 5 percent combined different methods (delivery, own transport, and on farm) to transport their production (Table A29). 


\subsection{Methods of Sale of Produce}

Ninety-two percent of gardeners sold their produce individually, whereas 5 percent made a joint sale, 1 percent sold under contract, and 1 percent combined individual and under-contract sales (Table 7). Of the gardeners who jointly sold their produce, most of them were satisfied, whereas the rest indicated three reasons for their dissatisfaction-they did not trust the management team or other members, the period of sale was later than their harvest period, and they did not agree with the low sale price (Tables A30 and A31).

Table 7. Methods of sale of produce.

\begin{tabular}{|c|c|c|}
\hline \multicolumn{3}{|c|}{ D5. How Do You Sell the Produce? } \\
\hline D5 & Count & Percent \\
\hline Joint sales & 12 & 4.60 \\
\hline Individual sales & 241 & 92.34 \\
\hline Under contract & 2 & 0.77 \\
\hline $\begin{array}{c}\text { Others (individual sale \& } \\
\text { under contract) }\end{array}$ & 2 & 0.77 \\
\hline $\mathrm{Na}$ & 4 & 1.53 \\
\hline \multicolumn{3}{|c|}{$N=261$} \\
\hline
\end{tabular}

Of gardeners who sold their produce individually, 86 percent were satisfied, whereas the rest were mostly willing to make a joint sale (Tables A32 and A33). The remainder of dissatisfied gardeners who sold individually and who were not willing to make a joint sale gave four reasons-they did not trust the management team or other members, they did not produce the same crops as other members, they had more liberty on the price, and they wanted to avoid quarrels (Table A34).

\subsection{Credit Sources from Financial Institutions}

Credit is of high importance for the gardening activity. Sixty percent of gardeners indicated that they had obtained credit from financial institutions, whereas 9 percent indicated that they obtained credit through a 'tontine' (In a simple tontine, a group of investors pool their money together to buy a portfolio of investments, and, as investors die, their shares are forfeited, with the entire fund going to the last surviving investor [43].)/informal group, 3 percent obtained credit from family members, and 19 percent had no access to credit (Table 8). Gardeners obtaining credit from a tontine/informal group and family members indicated that they chose this route because it was less risky, they had no guarantee, it had a low interest rate, and other reasons such as the desire to avoid long administrative procedures in financial institutions or because they had no access to formal credit (Tables A35 and A36).

Table 8. Credit from financial institutions.

\begin{tabular}{ccc}
\hline \multicolumn{3}{c}{ D6. Where Do You Get the Credit for Production? } \\
\hline D6 & Count & Percent \\
\hline From financial institutions & 156 & 59.77 \\
From a tontine/informal group & 24 & 9.20 \\
From family members & 7 & 2.68 \\
No access to credit & 50 & 19.16 \\
Na & 24 & 9.20 \\
\hline \multicolumn{3}{c}{$N=261$} \\
\hline
\end{tabular}

Gardeners indicated that they obtained credit either in a group (74 percent) or alone (20 percent) or both in a group and alone (2 percent) (Tables A37 and A38). When respondents were asked why they did not obtain credit in a group, they indicated different reasons: they depend on other members before 
obtaining formal credit, they would not actually obtain the amount they needed, they did not trust the management team or other members, and other reasons (e.g., we just started to obtain credit as a group) (Table A39). Of those who obtained credit for production, 40 percent indicated that the credit suited their needs (Table A40). Of those who were not satisfied with the credit, 79 percent indicated they were willing to obtain credit as a group (Table A41). Those who were not willing to obtain credit as a group cited different reasons - they depend on other members before obtaining additional credit, they did not trust the management team or other members anymore, and other reasons such as credit was insufficient and the high costs of credit (Tables A42 and A43). We may conclude that most gardeners self-organize themselves well to obtain credit as a group. However, the amount of credit is insufficient for most of them, and they are willing to obtain more credit as a group.

Gardeners used the credit for different purposes, but a high number of them ( 80 percent) used the credit for a combination of purposes (Table 9), such as purchase of fertilizer, seeds, pesticides, and garden equipment (61 percent) or fertilizer, seeds, and pesticides (36 percent) (Table A44). Regarding flexibility, 66 percent of gardeners indicated that they used the credit for its original purpose, whereas 23 percent sometimes changed the credit for unforeseen costs, crises at home, or their own needs (Tables A45 and A46). Among the latter gardeners (23 percent), in the previous year, unexpected changes hit 28 percent of them once, twice for 42 percent, three times for 19 percent, and four times or more for 5 percent (Table A47). We may conclude that most gardeners assign multiple functions to the credit and use it for its original purpose.

Table 9. Purpose of the credit.

\begin{tabular}{ccc}
\hline 6.3 For What Do You Use the Credit? & (More Than One Answer Possible) \\
\hline D63 & Count & Percent \\
\hline Purchase of fertilizer & 6 & 3.21 \\
Purchase of seeds & 7 & 3.74 \\
Purchase of garden equipment & 8 & 4.28 \\
A combination & 149 & 79.68 \\
Na & 17 & 9.09 \\
\hline \multicolumn{3}{c}{} \\
\hline
\end{tabular}

\subsection{Validation}

A focus group discussion (FGD) with 22 participants (20 male and female gardeners and two experts from local agencies of the Ministry of Agriculture of Cotonou and Porto-Novo) was organized to verify and discuss the main findings of the study on the organization, management, joint ventures and lack of credit for gardening. The discussions were summarized in the following points, and recommendations were added in the discussion section.

Good sense of organization and management (77 percent). The participants confirmed this finding and indicated that they were organized in cooperations that were registered and had bank accounts to receive their membership fees. The frequency of these fees' payments varied widely. In general, they indicated that the fees allowed them to make loans to members or to provide guarantees for taking credit, but this was not effective due to a lack of trust between members. They also indicated that there was good cohesion between their communal, departmental, and national representations.

Few gardeners formed joint ventures/partnerships to purchase inputs ( 23 percent) or sell produce (8 percent). The participants confirmed this result and explained that gardeners within the cooperations had different sale perspectives. Therefore, each gardener decided what to produce because the sale perspectives varied per product and per period, which did not easily enable joint sales. They also indicated the lack of land and the fact that the cultivated areas were scattered as two additional factors that prevented joint partnerships. In addition, they indicated the dissimilarity in the production itineraries as a brake on joint ventures because the products were ready at different times and the quality of the products sometimes differed among gardeners. 
Credit was insufficient and unsuitable for urban gardeners (60 percent). The gardeners confirmed the finding and added that besides the fact that the credit was insufficient, the conditions to obtain it were unsuitable for gardening (no deferred period, high interest rates, and short repayment period). They added that the reluctance of many financial structures to provide loans to gardeners was a constraint on them obtaining credit.

\section{Discussion}

The survey brought to light some notable insights on the gardening activity in two big cities of Benin on the following aspects: organization, functioning, and gaps in policy support.

\subsection{How Are Urban Gardeners Organized?}

There is a sense of need to collaborate among gardeners who, are mostly organized in cooperations and regularly subscribe (weekly, monthly, yearly) to a membership fee. This membership fee is intended to purchase fertilizer and seeds, but in practice gardeners individually purchase the needed inputs. The cooperations in most of the cases have a management team, elected in 50 percent of the cases. Gardeners also recognize the authority of the management team, share the responsibility for common tasks (site surveillance, participation in meetings, and offering help to other members) and have a constitution. The Focus Group Discussions (FGD) added that most of their cooperations are registered with the ministry of agriculture and have bank accounts that collect membership fees. Besides purchases, the fees are also aimed to provide guarantees for taking credit but, this is not effective due to a lack of trust between members. They also indicated that there is good cohesion between their communal and national representations. These elements provide a clear picture of the current situation, which can be compared with the seven principles put in place by ICA (Table 10). We may conclude that the management systems of cooperations are well structured in principle and most groups meet most of the principles. However, the cooperations have room for improvement on the following aspects: agreement on rules of ownership, member control, economic participation, autonomy, and concern for community.

Table 10. Comparison between ICA principles for cooperatives and urban gardeners' organizations.

\begin{tabular}{ll}
\hline \multicolumn{1}{c}{ ICA Cooperative Principles } & 29 Gardeners' Organizations \\
\hline (1) Voluntary and open membership & Present \\
(2) Democratic member control & Present in some \\
(3) Member economic participation & Present in some \\
(4) Autonomy and independence & Present in some \\
(5) Education, training, and information & Present in some \\
(6) Cooperation among cooperatives & Present \\
(7) Concern for community & Not present \\
\hline Source: Adapted from Kurimoto, Draperi, Bancel, Novkovic, Shaw, Wilson, and Cracogna [33].
\end{tabular}

\subsection{How Do Urban Gardeners' Cooperations Function?}

Our research found that very few gardeners form joint partnerships to purchase inputs and sell produce. We assume that this situation would increase their transaction costs and make room for financial incentives that encourage gardeners to form joint ventures to deal with outside partners (suppliers, clients). For instance, successful examples of effective collective actions on rural farmers' income can be found in Benin within cashew nuts farmers [44] and paddy rice producers [45], in Namibia [29], in South Africa [8], in Kenya within dairy farmers [46], in Ethiopia [5], and in the Andean region of South America within potato farmers [47]. Although, these examples are mostly for commercial and staple products (coffee, cashew nuts, potatoes, paddy rice), they provided evidence that participation in the market was one of the important factors that determined farmers' commitment in collective actions. Thus, these examples represent interesting case studies that can be used to 
convince gardeners on the economic benefits of engaging in joint ventures with their cooperations. In addition, there is a high and diversified demand for fruits and vegetables on the market [41], which also represents a nice incentive for gardeners. Already, gardeners who are dissatisfied with individual marketing experiences are willing to enter joint ventures if, in general, the issues of mistrust regarding members and the management team and adaptation to their needs are tackled. Hence, this may constitute a first entry point to experiment with joint ventures that may also influence the transport of produce, which is currently diversely dealt with by gardeners (own transport, taxi rental, etc.). Furthermore, our findings provide nice examples of joint ventures and showed that most gardeners who obtained credit, though insufficient, from financial institutions bargained as a group. This additional incentive corroborates the argument that collective actions may actually assure a common interest and provide assurance to a wide group of involved people. In that perspective, support from the national economic policy may also be needed to facilitate credit for farming which, in return, may indirectly have positive effects on collective actions among gardeners.

\subsection{How Can Policies Better Support Cooperations in Making Successful Ventures?}

Although the development of successful agricultural cooperatives requires efforts from various stakeholders-farmers, civil society, extension officers, scientists, policymakers, and technical and financial partners-policy support is needed to help urban gardeners sustainably develop their cooperations [31]. From that perspective, suggesting relevant policy interventions may require more knowledge on the current development stage of urban cooperations. We, therefore, used the life cycle theory of Cook $[34,36]$ to assess the evolution of gardeners' groups and formulate better interventions for their long-term functioning toward genuine cooperatives (Table 11). By comparing the five stages of the life cycle to the current situation of cooperations, we may conclude that urban cooperations are still in the early stages of development and are facing internal constraints substantiated by two factors: small, joint partnerships to improve bargaining power and the vaguely defined rules of ownership among members. We may, therefore, recommend that policies foster collective actions among gardeners to improve their incomes and livelihoods. Although the task is difficult to organize and manage, the literature proposes guidelines and conditions to enhance the success of collective marketing. For example, Markelova et al. [48] reviewed the literature on a special issue and found that besides groups characteristics, it is often required that the public sector provides both financial and capacity building to farmers and that policies ensure their access to stable and competitive markets. In a study in Meso-America, Hellin et al. [49] also highlighted the central role of governments in determining how markets should function to create an enabling policy environment, especially in the vegetables sector, characterized by high transaction costs. In the same perspective, the FGD corroborated the latter conditions and pointed out three recommendations for local and national agricultural policies that may encourage gardeners in succeeding in their endeavors. First, creation of gardening markets by municipalities where gardeners can route their products for sale to facilitate aggregation of gardeners' harvests within their cooperations. Second, reduction of vegetable imports by national policymakers may increase and protect the demand for vegetables and thereby gardeners' incomes. This recommendation may learn from the European Common Agricultural Policy Reform and the unexpected outputs of protectionist measures where subsidies and taxation did not systematically increase the demand for fruits and vegetables. Rather, these measures must be combined with consumer information provision about healthy diets to succeed [50]. The last recommendation refers to raising awareness among gardeners about the best ways to manage their cooperations and effectively make collective actions. 
Table 11. Comparing Cook's stages of the cooperative life cycle to the current situation.

\begin{tabular}{ll}
\hline \multicolumn{1}{c}{ Stages of Life Cycle } & Current Situation \\
\hline (1) Phase one: Economic justification & Completed \\
(2) Phase two: Organizational design & Ongoing/Completed \\
(3) Phase three: Growth, glory, and heterogeneity & Ongoing \\
(4) Phase four: Recognition and introspection & Not yet \\
(5) Phase five: Choice & Not yet \\
\hline
\end{tabular}

Source: Adapted from Cook [36].

Moreover, sensitization and capacity-building of gardeners on marketing, conflict management, partnership and, especially, financial management are important to avoid situations where the few financial institutions consider financing to be too risky and decide to stop the venture. Indeed, our findings showed that about a quarter of gardeners modify their credit purposes when unforeseen costs or crises arise at home. As a result, this unfortunate situation may discourage financial institutions from investing in agriculture. We therefore recommend that, beyond gardeners' efforts to improve cooperation, agricultural and economic policies support the process as follows: assigning extension workers to gardeners to emphasize financial management to ensure long-term sustainability even in the absence of outside partners; and establishing a guarantee fund, which may encourage financial institutions to take more risks in agriculture financing. These recommendations are consistent with the literature on agricultural cooperatives, which emphasizes the importance of capacity building programs in enhancing collective actions. For instance, recent quantitative studies on the impact of collective marketing of paddy rice on the livelihoods of smallholders farmers in Benin [45] and the analysis of factors affecting proper functioning of smallholder cooperatives in the Limpopo Province of South Africa [51] concluded that better training through extension officers on technical skills such as financial management and conflict management is one of the important factors that may sustain cooperations. These recommendations may also learn from the European Common Agricultural Policy Reform and the unexpected outputs of financing measures, where eligibility criteria eliminated small and vulnerable farmers from technical and financial support [52]. Therefore, it is vital that policy measures explore and adapt the recommendations to the local settings.

Our study is replicable in other contexts thanks to its methodology that clearly described the transdisciplinary approach that combined academic knowledge and local knowledge to create a common knowledge base that can inform policies. In addition, the stratified random selection made the results generalizable to the entire population of urban gardeners of the two cities. Therefore, our research is worth spreading because the conclusions would guide current cooperations, practitioners, and policymakers in an incremental transition to genuine cooperatives. Furthermore, because our study cities were the most urbanized areas in the country, we suspect similar observations in other urban settings in the country, which makes our conclusions useful to other cooperations in similar situations. Moreover, our research found that urban gardeners, within their cooperations, mostly made their decisions individually (e.g., cultivated crops, type of fertilizer to use, marketing) and collectively (e.g., protection, land acquisition). Hence, future endeavors to improve cooperation among gardeners requires a deep study of the effects of individual and collective decision-making on cooperatives' performance. Additionally, future research could concentrate on the development of value chains that can be jointly organized by participating gardeners.

\section{Conclusions and Way Forward}

Our research attempted to contribute to the international debate on the management of urban agriculture through development of cooperatives in developing countries. We explored and compared international standards to prevailing organizations and their functioning among 261 gardeners in two cities in Benin. We found that most urban gardeners were well organized and established good management rules that may help their cooperations thrive in the future. Nevertheless, they still had to improve their functioning by enhancing collective actions that may truly leverage their bargaining 
power, reduce transaction costs, and improve incomes and livelihoods. However, enhancing collective actions within their cooperations would not be an easy task and requires coordinated efforts from various stakeholders-gardeners, civil society, scientists, policymakers, and technical and financial partners-to help urban gardeners succeed sustainably in their cooperations. We recommended that (i) national agricultural policies focus on assigning extension workers to build continuously the capacities of gardeners on collective actions and on reducing vegetables imports to increase and protect the demand for vegetables; (ii) local agricultural policies focus on creating gardening markets where gardeners can route their products for sale to facilitate aggregation of gardeners' harvests within their cooperations; and (iii) national economic policies support agriculture by establishing a guarantee fund within financial institutions to invest in agriculture financing and encourage joint access by gardeners, which indirectly promote collective actions.

Author Contributions: Conceptualization, D.M.H., B.G.J.S.S., A.K.N.A. and F.S.T.; Data curation, D.M.H.; Formal analysis, D.M.H., B.G.J.S.D., A.K.N.A., F.S.T. and S.A.R.D.; Funding acquisition, B.G.J.S.D.; Investigation, D.M.H.; Methodology, D.M.H. and B.G.J.S.D.; Project administration, B.G.J.S.D.; Supervision, T.D.C.B.; Visualization, D.M.H. and B.G.J.S.D.; Writing—original draft, D.M.H.; Writing—review \& editing, B.G.J.S.D., A.K.N.A., D.J.R.M.S., A.A.A., and T.D.C.B.

Funding: Nederlandse Organisatie voor Wetenschappelijk Onderzoek: File no: 08.260.302. Nuffic: R/003248.01.

Conflicts of Interest: The authors declare no conflicts of interest.

\section{Appendix A}

Table A1. Type of organizations.

\begin{tabular}{ccc}
\hline \multicolumn{3}{c}{ D1.1 What Is the Type of Organization? } \\
\hline D11 & Count & Percent \\
\hline Informal group & 11 & 4.74 \\
Cooperative & 219 & 94.40 \\
$\mathrm{Na}$ & 2 & 0.86 \\
\hline \multicolumn{3}{c}{$N=232$} \\
\hline
\end{tabular}

Table A2. Members of the organization.

\begin{tabular}{ccccccccc}
\hline \multicolumn{7}{c}{ D1.2 How Many Persons Are Members of the Organization? } \\
\hline \multicolumn{7}{c}{ D1.2.1 How Many Men Are Members of the Organization? } \\
\hline D1.2.2 How Many Women Are Members of the Organization? \\
\hline Variable & Count & $N^{*}$ & Mean & Minimum & Q1 & Median & Q3 & Maximum \\
\hline D12 & 229 & 3 & 73.48 & 6.00 & 12.00 & 42.00 & 60.00 & 400.00 \\
D121 & 226 & 6 & 58.95 & 0.000000000 & 9.00 & 37.00 & 54.00 & 310.00 \\
D122 & 229 & 6 & 14.74 & 0.000000000 & 3.00 & 5.00 & 10.00 & 100.00 \\
\hline \multicolumn{7}{c}{ * Missing information. }
\end{tabular}

Table A3. Membership fees.

\begin{tabular}{ccc}
\hline \multicolumn{2}{c}{ D1.3 Do You Pay a Contribution to the Organization? } \\
\hline D13 & Count & Percent \\
\hline No & 52 & 22.41 \\
Yes & 179 & 77.16 \\
NA & 1 & 0.43 \\
\hline \multicolumn{3}{c}{} \\
\hline
\end{tabular}


Table A4. Membership fees: periodicity.

\begin{tabular}{ccc}
\hline D1.3.1 What Is the Periodicity of the Contributions? \\
\hline D131 & Count & Percent \\
\hline Bimonthly & 16 & 8.94 \\
Daily & 4 & 2.23 \\
Four-monthly & 9 & 5.03 \\
Half-yearly & 1 & 0.56 \\
Monthly & 55 & 30.73 \\
Quarterly & 2 & 1.12 \\
Weekly & 36 & 20.11 \\
When needed & 10 & 5.59 \\
Yearly & 46 & 25.70 \\
\hline
\end{tabular}

Table A5. Membership fees: paid contributions, respectively, by month, year, and week.

\begin{tabular}{ccccccccc}
\hline \multicolumn{7}{c}{ D1.3.2 What Contribution Do You Pay to the Group per Period? } \\
\hline Variable & Count & $N^{*}$ & Mean & Minimum & Q1 & Median & Q3 & Maximum \\
\hline D132 & 55 & 0 & 1844 & 200 & 1000 & 1500 & 2500 & 10000 \\
D132_1 & 46 & 0 & 2846 & 100 & 2000 & 2000 & 2000 & 12000 \\
D132_2 & 36 & 0 & 438.9 & 100.0 & 500.0 & 500.0 & 500.0 & 500.0 \\
\hline
\end{tabular}

${ }^{*}$ Missing information.

Table A6. Membership fees: purpose of the contribution (first choice).

\begin{tabular}{ccc}
\hline D1.3.3 What Is the Contribution Fee For? & (More Than One Answer Possible) \\
\hline D133_8 & Count & Percent \\
\hline Common land lease & 4 & 2.23 \\
Common land purchase & 19 & 10.61 \\
Purchase of fertilizer & 77 & 43.02 \\
Purchase of seeds & 5 & 2.79 \\
Purchase of garden equipment & 14 & 7.82 \\
Credit to members & 6 & 3.35 \\
Social help to members & 22 & 12.29 \\
Others & 29 & 16.20 \\
NA & 3 & 1.68 \\
\hline
\end{tabular}

Table A7. Membership fees: purpose of the contribution (second choice).

\begin{tabular}{ccc}
\hline D1.3.3 What Is the Contribution Fee For? & (More Than One Answer Possible) \\
\hline D133_2 & Count & Percent \\
\hline Common land purchase & 4 & 2.23 \\
Purchase of fertilizer & 8 & 4.47 \\
Purchase of seeds & 65 & 36.31 \\
Purchase of garden equipment & 7 & 3.91 \\
Credit to members & 9 & 5.03 \\
Social help to members & 8 & 4.47 \\
NA & 78 & 43.58 \\
\hline
\end{tabular}


Table A8. Election of the committee.

\begin{tabular}{ccc}
\hline \multicolumn{3}{c}{ D1.4.1 Is the Committee Elected? } \\
\hline D141 & Count & Percent \\
\hline No & 115 & 50.22 \\
Yes & 114 & 49.78 \\
\hline \multicolumn{3}{c}{} \\
\hline
\end{tabular}

Table A9. Election of the committee: formation of the committee.

\begin{tabular}{ccc}
\hline \multicolumn{3}{c}{ D1.4.2 How Was the Committee Formed? } \\
\hline D142 & Count & Percent \\
\hline By the first occupants of the land & 10 & 8.70 \\
By the elders & 20 & 17.39 \\
Others & 85 & 73.91 \\
\hline \multicolumn{3}{c}{} \\
\hline
\end{tabular}

Table A10. Election of the committee: other formation of the committee.

\begin{tabular}{ccc}
\hline D142 Others & Count & Percent \\
\hline Ability to manage & 16 & 18.82 \\
Honesty & 4 & 4.71 \\
NA & 7 & 8.24 \\
Simple designation & 58 & 68.24 \\
\hline \multicolumn{3}{c}{$N=85$} \\
\hline
\end{tabular}

Table A11. Term of the committee.

\begin{tabular}{ccc}
\hline D1.4.3 Does the Committee Have a Term? \\
\hline D143 & Count & Percent \\
\hline No & 55 & 24.02 \\
Yes & 174 & 75.98 \\
\hline \multicolumn{3}{c}{} \\
\hline
\end{tabular}

Table A12. Acknowledgment of the authority of the cooperative leader/board.

\begin{tabular}{ccc}
\hline D1.5 Do You Acknowledge the Authority of the Cooperative Leader/Board? \\
\hline D143 & Count & Percent \\
\hline No & 9 & 3.88 \\
Yes & 222 & 95.69 \\
NA & 1 & 0.43 \\
\hline
\end{tabular}

Table A13. Acknowledgment of board authority: reason for no acknowledgment.

\begin{tabular}{ccc}
\hline D1.5.1 Why Don't You Acknowledge the Authority of the Cooperative Leader/Board? \\
\hline D151 & Count & Percent \\
\hline I don't trust the leader/board & 3 & 33.33 \\
No value addition & 5 & 55.56 \\
NA & 1 & 11.11 \\
\hline
\end{tabular}


Table A14. Share of the responsibility of common tasks: actual practice.

\begin{tabular}{ccc}
\hline \multicolumn{3}{c}{ D1.7 Does This Work in Practice? } \\
\hline D17 & Count & Percent \\
\hline No & 30 & 12.93 \\
Yes & 195 & 84.05 \\
NA & 7 & 3.02 \\
\hline \multicolumn{3}{c}{} \\
\hline
\end{tabular}

Table A15. Existence of a constitution.

\begin{tabular}{ccc}
\hline \multicolumn{3}{c}{ D1.8 Does the Organization Have a Constitution? } \\
\hline D18 & Count & Percent \\
\hline No & 3 & 1.29 \\
Yes & 228 & 98.28 \\
NA & 1 & 0.43 \\
\hline \multicolumn{3}{c}{} \\
\hline
\end{tabular}

Table A16. Agreement on rules of ownership aspects.

D1.9 Is There an Agreement on Rules of Ownership Aspects (Individual Plots or Communal Lands/Fair Share of Profits)?

\begin{tabular}{ccc}
\hline D19 & Count & Percent \\
\hline No & 129 & 55.60 \\
Yes & 102 & 43.97 \\
NA & 1 & 0.43 \\
\hline & $N=232$ & \\
\hline
\end{tabular}

Table A17. Lease contract: amount paid per month.

\begin{tabular}{ccccccccc}
\hline \multicolumn{10}{c}{ D2.1 How Much CFA per Month Do You Pay for Leasing the Area? } \\
\hline Variable & Count & $N^{*}$ & Mean & Minimum & Q1 & Median & Q3 & Maximum \\
\hline D21 & 17 & 0 & 12588 & 1000 & 1000 & 4000 & 7000 & 57000 \\
\hline \multicolumn{10}{c}{ * Missing information. }
\end{tabular}

Table A18. Lease contract: duration of the contract in years.

\begin{tabular}{ccccccccc}
\hline \multicolumn{10}{c}{ D2.1 How Long Did You Lease the Area For? } \\
\hline Variable & Count & $N^{*}$ & Mean & Minimum & Q1 & Median & Q3 & Maximum \\
\hline D211 & 16 & 1 & 3.563 & 2.000 & 2.000 & 2.000 & 5.000 & 10.000 \\
\hline \multicolumn{10}{c}{ * Missing information. }
\end{tabular}

Table A19. Lease contract: existence of contract.

\begin{tabular}{ccc}
\hline \multicolumn{2}{c}{ D2.1.2 Is There a Contract } & (Written or Verbal)? \\
\hline D212 & Count & Percent \\
\hline No & 1 & 5.88 \\
Yes & 16 & 94.12 \\
\hline \multicolumn{3}{c}{} \\
\hline
\end{tabular}


Table A20. Free access contract: type of owner.

\begin{tabular}{ccc}
\hline \multicolumn{3}{c}{ D2.2 Who Gives You Free Access? } \\
\hline D22 & Count & Percent \\
\hline Private person & 16 & 12.31 \\
Private institution & 14 & 10.77 \\
Public institution & 80 & 61.54 \\
Others & 12 & 9.23 \\
NA & 8 & 6.15 \\
\hline
\end{tabular}

Table A21. Free access contract: other types of owners.

\begin{tabular}{ccc}
\hline D22 Others & Count & Percent \\
\hline A public institution (ASECNA) & 11 & 8.46 \\
A public space & 3 & 2.31 \\
NA & 114 & 87.69 \\
Unidentified area & 2 & 1.54 \\
\hline \multicolumn{2}{c}{$N=130$} \\
\hline
\end{tabular}

Table A22. Free access contract: duration of the contract in years.

\begin{tabular}{ccccccccc}
\hline \multicolumn{8}{c}{ D2.2.1 For How Long Is Your Free Access Contract with the Owner (In Years)? } \\
\hline Variable & Count & $N^{*}$ & Mean & Minimum & Q1 & Median & Q3 & Maximum \\
\hline D221 & 17 & 113 & 14.84 & 0.250 & 1.50 & 5.00 & 31.00 & 50.00 \\
\hline \multicolumn{8}{c}{${ }^{*}$ Missing information. }
\end{tabular}

Table A23. Free access contract: existence of contract.

\begin{tabular}{ccc}
\hline \multicolumn{3}{c}{ D2.2.2 Is There a Contract (Written or Verbal)? } \\
\hline D222 Others & Count & Percent \\
\hline No & 40 & 30.77 \\
Yes & 50 & 38.46 \\
NA & 40 & 30.77 \\
\hline \multicolumn{3}{c}{} \\
\hline
\end{tabular}

Table A24. Number of years of gardening in the area.

\begin{tabular}{|c|c|c|c|c|c|c|}
\hline \multicolumn{7}{|c|}{ D2.3 For How Long Have You Worked in the Area (In Years } \\
\hline Variable & Count & $N^{*}$ & Mean & Minimum & Q1 & Median \\
\hline \multirow[t]{9}{*}{ D23 } & 190 & 71 & 13.674 & 1.000 & 6.000 & 10.000 \\
\hline & & \multicolumn{5}{|c|}{${ }^{*}$ Missing information. } \\
\hline & & \multicolumn{5}{|c|}{ Table A25. Joint purchase: satisfaction of gardeners. } \\
\hline & & \multicolumn{5}{|c|}{ D3.1. Are Joint Purchases Well Organized? } \\
\hline & & \multicolumn{2}{|c|}{ D31 } & Count & \multicolumn{2}{|c|}{ Percent } \\
\hline & & \multicolumn{2}{|c|}{ No } & 5 & \multicolumn{2}{|r|}{9.43} \\
\hline & & \multicolumn{2}{|c|}{ Yes } & 47 & \multicolumn{2}{|r|}{88.68} \\
\hline & & \multicolumn{2}{|c|}{ NA } & 1 & \multicolumn{2}{|r|}{1.89} \\
\hline & & \multicolumn{5}{|c|}{$N=53$} \\
\hline
\end{tabular}


Table A26. Joint purchase: reason for no satisfaction.

\begin{tabular}{ccc}
\hline \multicolumn{3}{c}{ D3.1.1 What Is Not Functioning? } \\
\hline D311 & Count & Percent \\
\hline The quantity does not suit my need & 2 & 40.00 \\
I don't trust the management team/other members & 1 & 20.00 \\
NA & 2 & 40.00 \\
\hline \multicolumn{2}{c}{$N=5$} \\
\hline
\end{tabular}

Table A27. Individual purchase: satisfaction of gardeners.

\begin{tabular}{ccc}
\hline D3.2. Do Individual Purchases Satisfy & Your Needs? \\
\hline D32 & Count & Percent \\
\hline No & 51 & 25.50 \\
Yes & 146 & 73.00 \\
NA & 3 & 1.50 \\
\hline \multicolumn{3}{c}{} \\
\hline
\end{tabular}

Table A28. Individual purchase: willingness to make a joint purchase.

\begin{tabular}{ccc}
\hline \multicolumn{2}{c}{ D3.2.1 Would You Like to Make a Joint Purchase? } \\
\hline D321 & Count & Percent \\
\hline Yes & 49 & 96.08 \\
NA & 2 & 3.92 \\
\hline \multicolumn{3}{c}{} \\
\hline
\end{tabular}

Table A29. Organization of the transport of produce.

\begin{tabular}{ccc}
\hline \multicolumn{2}{c}{ D4. How Do You Organize the Transport of the Produce to Clients? } \\
\hline D31 & Count & Percent \\
\hline Own transport & 67 & 25.67 \\
Taxi rental & 6 & 2.30 \\
I sell the produce on farm & 175 & 67.05 \\
Others (delivery, own transport, and on farm) & 13 & 4.98 \\
\hline \multicolumn{3}{c}{$N=261$} \\
\hline
\end{tabular}

Table A30. Joint sales: satisfaction of gardeners.

\begin{tabular}{ccc}
\hline \multicolumn{3}{c}{ D5.1 Are Sales Well Organized? } \\
\hline D51 & Count & Percent \\
\hline No & 4 & 33.33 \\
Yes & 8 & 66.67 \\
\hline \multicolumn{3}{c}{$N=12$} \\
\hline
\end{tabular}


Table A31. Joint sales: reason for no satisfaction.

\begin{tabular}{ccc}
\hline \multicolumn{4}{c}{ D5.1.1 What Is Not Functioning? } \\
\hline D511 & Count & Percent \\
\hline $\begin{array}{c}\text { I don't trust the management team/other members } \\
\text { The period of sale does not correspond to my } \\
\text { harvest period }\end{array}$ & 1 & 25.00 \\
I don't agree with the sales price & 2 & 50.00 \\
$N=4$ & 1 & 25.00 \\
\hline
\end{tabular}

Table A32. Individual sales: satisfaction of gardeners.

\begin{tabular}{ccc}
\hline \multicolumn{3}{c}{ D5.2. } \\
\hline D51 & Count & Pou Satisfied? \\
\hline No & 33 & 13.69 \\
Yes & 206 & 85.48 \\
$\mathrm{Na}$ & 2 & 0.83 \\
\hline \multicolumn{3}{c}{$\mathrm{N}=241$} \\
\hline
\end{tabular}

Table A33. Individual sales: willingness to make a joint sale.

\begin{tabular}{ccc}
\hline \multicolumn{3}{c}{ D5.2.1 Would You Like to Make a Joint Sale? } \\
\hline D521 & Count & Percent \\
\hline No & 5 & 15.15 \\
Yes & 28 & 84.85 \\
\hline \multicolumn{3}{c}{} \\
\hline
\end{tabular}

Table A34. Individual sales: reason for the unwillingness.

\begin{tabular}{ccc}
\hline \multicolumn{3}{c}{ D5.2.2 Would You Like to Make a Joint Sale? } \\
\hline D522 & Count & Percent \\
\hline I don't trust the management team/other members & 1 & 20.00 \\
I don't produce the same products as the other members & 1 & 20.00 \\
I have more liberty on the price & 2 & 40.00 \\
Others (to avoid quarrels) & 1 & 20.00 \\
\hline & & \\
\hline
\end{tabular}

Table A35. Credit from tontine and family members: reason for this choice.

\begin{tabular}{ccc}
\hline \multicolumn{3}{c}{ D6.1. Why Do You Get Your Credit from Tontine/Family Members? } \\
\hline D61 & Count & Percent \\
\hline Lack of collateral to get credit from & 8 & 25.81 \\
financial institutions & 8 & 25.81 \\
Low interest rate & 10 & 32.26 \\
Less risky & 4 & 12.90 \\
Others & 1 & 3.23 \\
NA &
\end{tabular}


Table A36. Table A36. Credit from tontine and family members: other reasons for this choice.

\begin{tabular}{ccc}
\hline D61 Others & Count & Percent \\
\hline Long procedure in financial institution & 1 & 25.00 \\
No access to formal credit & 3 & 75.00 \\
\hline \multicolumn{2}{c}{$N=4$} & \\
\hline
\end{tabular}

Table A37. Mechanism to obtain credit.

\begin{tabular}{|c|c|c|}
\hline \multicolumn{3}{|c|}{ D6.2 To Whom Is the Credit Assigned? } \\
\hline D62 Others & Count & Percent \\
\hline To a group & 138 & 73.80 \\
\hline To me alone & 38 & 20.32 \\
\hline Others & 4 & 2.14 \\
\hline NA & 7 & 3.74 \\
\hline \multicolumn{3}{|c|}{$N=187$} \\
\hline
\end{tabular}

Table A38. Mechanism to obtain credit: others.

\begin{tabular}{ccc}
\hline D62 Others & Count & Percent \\
\hline As a group and alone & 4 & 100.00 \\
\hline \multicolumn{3}{c}{$N=4$} \\
\hline
\end{tabular}

Table A39. Reasons for credit not in a group.

\begin{tabular}{ccc}
\hline \multicolumn{3}{c}{ D6.2.1 Why Don't You Take Your Credit as a Group? } \\
\hline D621 Others & Count & Percent \\
\hline I don't trust the management team/other members & 7 & 16.67 \\
I will not actually get the amount I need & 9 & 21.43 \\
I depend on other members before getting formal credit & 17 & 40.48 \\
Others (we just started to obtain credit as a group) & 5 & 11.90 \\
NA & 4 & 9.52 \\
\hline & $N=42$ & \\
\hline
\end{tabular}

Table A40. Credit satisfaction.

\begin{tabular}{|c|c|c|}
\hline \multicolumn{3}{|c|}{ D6.2.2 Does the Credit Suit Your Need? } \\
\hline D622 & Count & Percent \\
\hline No & 104 & 55.61 \\
\hline Yes & 75 & 40.11 \\
\hline NA & 8 & 4.28 \\
\hline \multicolumn{3}{|c|}{$N=187$} \\
\hline
\end{tabular}

Table A41. Credit satisfaction: willingness to obtain credit as a group.

\begin{tabular}{ccc}
\hline D6.2.3 Would You Like to Get More Credit as a Group? \\
\hline D623 & Count & Percent \\
\hline No & 18 & 17.31 \\
Yes & 82 & 78.85 \\
NA & 4 & 3.85 \\
\hline \multicolumn{3}{c}{} \\
\hline
\end{tabular}


Table A42. Credit satisfaction: reasons for the unwillingness to obtain credit in a group.

\begin{tabular}{ccc}
\hline D6.2.4 Why Don't You Want to Obtain More Credit as a Group? & Count & Percent \\
\hline I don't trust the management team/other members & 1 & 5.56 \\
Because I depend on other members before getting formal credit & 14 & 77.78 \\
Others & 3 & 16.67 \\
\hline \multicolumn{2}{c}{$N=18$} \\
\hline
\end{tabular}

Table A43. Credit satisfaction: other reasons for the unwillingness to obtain credit as a group.

\begin{tabular}{ccc}
\hline D624 Others & Count & Percent \\
\hline Credit not sufficient & 2 & 66.67 \\
High costs for credit & 1 & 33.33 \\
\hline \multicolumn{2}{c}{$N=3$} \\
\hline
\end{tabular}

Table A44. Purpose of the credit: multi-functions.

\begin{tabular}{ccc}
\hline D63 & Count & Percent \\
\hline Purchase of fertilizer and purchase of seeds & 1 & 0.67 \\
Purchase of fertilizer; purchase of seeds and purchase of pesticides & 53 & 35.57 \\
Purchase of fertilizer; purchase of seeds; purchase of pesticides and purchase of & 91 & 61.07 \\
garden equipment & 1 & 0.67 \\
Purchase of fertilizer; purchase of seeds and purchase of garden equipment & 2 & 1.34 \\
Purchase of seeds; purchase of pesticides and purchase of garden equipment & 1 & 0.67 \\
NA & & \\
\hline
\end{tabular}

Table A45. Flexibility of the purpose of credit.

\begin{tabular}{ccc}
\hline D6.3.1 Are You Always Focused on the Original Purpose of the Credit? \\
\hline D631 & Count & Percent \\
\hline No & 43 & 22.99 \\
Yes & 124 & 66.31 \\
NA & 20 & 10.70 \\
\hline \multicolumn{3}{c}{} \\
\hline
\end{tabular}

Table A46. Flexibility of the purpose of credit: reasons for a change in purpose.

\begin{tabular}{|c|c|c|}
\hline D632 & Count & Percent \\
\hline When unforeseen costs/distressing situations appear at home & 40 & 93.02 \\
\hline Others (own needs) & 3 & 6.98 \\
\hline
\end{tabular}

Table A47. Frequency of the situation for a change in purpose of credit.

\begin{tabular}{ccc}
\hline D6.3.3 How Many Times Did This Situation Happen during the Last Year? \\
\hline D633 & Count & Percent \\
\hline 1 & 12 & 27.91 \\
2 & 18 & 41.86 \\
3 & 8 & 18.60 \\
4 & 1 & 2.33 \\
Many times & 1 & 2.33 \\
NA & 3 & 6.98 \\
\hline
\end{tabular}




\section{References}

1. FAO. Spotlight: Issues in Urban Agriculture. Agriculture 21 Magazine; FAO: Rome, Italy, January 1999.

2. Van Veenhuizen, R. Cities Farming for the Future: Urban Agriculture for Green and Productive Cities; IDRC: Ottawa, ON, Canada, 2014.

3. Dubelling, M.; de Zeeuw, H.; van Veenhuizen, R. Cities, Poverty and Food. Multi-Stakeholder Policy and Planning in Urban Agriculture; RUAF Foundation, Practical Action Publishing: Rugby, UK, 2010.

4. Schmidt, S. Getting the policy right: Urban agriculture in Dar es Salaam, Tanzania. Int. Dev. Plan. Rev. 2012, 34, 129-145. [CrossRef]

5. Abate, G.T. Drivers of agricultural cooperative formation and farmers' membership and patronage decisions in Ethiopia. J. Co-Op. Organ. Manag. 2018, 6, 53-63. [CrossRef]

6. McCarthy, O.; Briscoe, R.; Ward, M. People in Control: The Promise of the Co-operative Business Approach. In Irish Business and Society: Governing, Participating and Transforming in the 21 st Century; Gill and MacMillan Dublin: Dublin, Ireland, 2010; pp. 319-366.

7. Briscoe, R.; Grey, S.; Hunt, P.; Linehan, M.; McBride, H.; Tucker, V. The Co-Operative Idea; Centre for Cooperative studies, University College Cork: Cork, Ireland, 1982.

8. Ortmann, G.F.; King, R.P. Agricultural cooperatives I: History, theory and problems. Agrekon 2007, 46, 18-46. [CrossRef]

9. Birchall, J.; Ketilson, L.H. Resilience of the Cooperative Business Model in Times of Crisis; International Labour Organisation: Geneva, Switzerland, 2009.

10. Briscoe, R.; Ward, M.J. The Competitive Advantages of Co-Operatives; Centre for Co-operative Studies; National University of Ireland: Cork, Ireland, 2000.

11. Kormelinck, A.G.; Plaisier, C.; Muradian, R.; Ruben, R. 6. Social capital and agricultural cooperatives: experimental evidence from Ethiopia. In Cooperatives, Economic Democratization and Rural Development; Edward Elgar Publishing: Cheltenham, UK, 2016; pp. 123-150.

12. Tefera, D.A.; Bijman, J.; Slingerland, M.A. Agricultural co-operatives in Ethiopia: Evolution, functions and impact. J. Int. Dev. 2017, 29, 431-453. [CrossRef]

13. World Bank. Agriculture for Development: World Development Report 2008; World Bank: Washington, DC, USA, 2007.

14. Berdegué, J. Cooperating to compete associative Peasant Business firms in Chile. The Netherlands: Wageningen University and Research Centre. Social Science Department. Innov. Commun. Group Wagening. 2001. Dissertation, externally prepared.

15. Chen, M.; Jhabvala, R.; Kanbur, R.; Richards, C. Membership Based Organizations of the Poor; Routledge: London, UK, 2007.

16. Iliopoulos, C.; Valentinov, V. Cooperative Longevity: Why are So Many Cooperatives So Successful? Multidisciplinary Digital Publishing Institute: Basel, Switzerland, 2018.

17. Fanasch, P.; Frick, B. What Makes Cooperatives Successful? Identifying the Determinants of Their Organizational Performance. J. Wine Econ. 2018, 13, 282-308. [CrossRef]

18. Cazzuffi, C.; Moradi, A. Membership Size and Cooperative Performance: Evidence from Ghanaian Cocoa Producers' Societies, 1930-1936. Econ. Hist. Dev. Reg. 2012, 27, 67-92.

19. Valentinov, V. Why are cooperatives important in agriculture? An organizational economics perspective. J. Inst. Econ. 2007, 3, 55-69. [CrossRef]

20. Bonus, $\mathrm{H}$. The cooperative association as a business enterprise: A study in the economics of transactions. J. Inst. Theor. Econ. (JITE)/zeitschrift Für Die Gesamte Staatswissenschaft 1986, 142, 310-339.

21. Staatz, J.M. Farmers' incentives to take collective action via cooperatives: A transaction cost approach. Cooperative Theory New Approaches 1987, 18, 87-107.

22. Bonin, J.P.; Jones, D.C.; Putterman, L. Theoretical and empirical studies of producer cooperatives: Will ever the twain meet? J. Econ. Lit. 1993, 31, 1290-1320.

23. Karantininis, K.; Zago, A. Endogenous membership in mixed duopsonies. Am. J. Agric. Econ. 2001, 83, 1266-1272. [CrossRef] 
24. Gentzoglanis, A. Economic and financial performance of cooperatives and investor-owned firms: An empirical study. In Strategies and Structures in the Agro-food Industries. Van Gorcum; Nilsson, J., van Dijk, G., Eds.; Van Gorcum: Assen, The Netherlands, 1997; pp. 171-182.

25. Cakir, M.; Balagtas, J.V. Estimating market power of US dairy cooperatives in the fluid milk market. Am. J. Agric. Econ. 2012, 94, 647-658. [CrossRef]

26. Albanese, M.; Navarra, C.; Tortia, E.C. Employer moral hazard and wage rigidity. The case of worker owned and investor owned firms. Int. Rev. Law Econ. 2015, 43, 227-237. [CrossRef]

27. Bernard, T.; Taffesse, A.S.; Gabre-Madhin, E. Impact of cooperatives on smallholders' commercialization behavior: Evidence from Ethiopia. Agric. Econ. 2008, 39, 147-161. [CrossRef]

28. Rashid, S.; Tefera, N.; Minot, N.; Ayele, G. Can modern input use be promoted without subsidies? An analysis of fertilizer in Ethiopia. Agric. Econ. 2013, 44, 595-611. [CrossRef]

29. Thomas, B.; Hangula, M.M. Reviewing theory, practices and dynamics of agricultural cooperatives: Understanding cooperatives development in Namibia. J. Dev. Agric. Econ. 2011, 3, 695-702.

30. OHADA. Acte Uniforme Relatif Au Droits des Societes Cooperatives; OHADA: Yaounde, Cameroon, 2011.

31. Gning, T.; Larue, F. Le nouveau modèle coopératif dans l'espace OHADA: Un outil pour la professionnalisation des organisations paysannes? Fondation Pour L'agriculture et la Ruralité Dans Le Monde (FARM) 2014.

32. Ostrom, E. Social cooperation in collective-action situations. Neue Kölner Genossenschaftswissenschaft 2009.

33. Kurimoto, A.; Draperi, J.; Bancel, J.; Novkovic, S.; Shaw, L.; Wilson, M.; Cracogna, D. Guidance Notes to the Co-operative Principles. Consult. Em 2015, 10, 2016.

34. Cook, M.L. The future of US agricultural cooperatives: A neo-institutional approach. Am. J. Agric. Econ. 1995, 77, 1153-1159. [CrossRef]

35. Iliopoulos, C.; Cook, M. The Organizational, Financial and Ownership Characteristics of US Agricultural Cooperatives: Survey Results from a New Institutional Economics Perspective; Strategies Cooperation, Shaker Verlag Publishing: Aachen, Germany, 2005; pp. 301-324.

36. Cook, M.L. A life cycle explanation of cooperative longevity. Sustainability 2018, 10, 1586. [CrossRef]

37. INSAE. Principaux Indicateurs Socio-Démographiques Et Economiques (RGPH-4, 2013); INSAE: Benin, 2016 ; p. 27.

38. WorldAtlas. The Major Cities of Benin. 2018. Available online: https://www.worldatlas.com/articles/themajor-cities-of-benin.html (accessed on 22 November 2018).

39. Yamane, T. Statistics: An Introductory Analysis; Harper: New York, NY, USA, 1973.

40. Cochran, W.G. Sampling Techniques, 3rd ed.; Wiley: New York, NY, USA, 1977.

41. Houessou, D.; Thoto, F.; Sonneveld, B.; Aoudji, A.; Dossou, S.; Agbandou, B. Urban Agriculture in Benin: How Can Policy Support Gardeners? ResearchGate: Berlin, Germany, 2019; Volume 80. [CrossRef]

42. Mazzarol, T.; Clark, D.; Reboud, S.; Limnios, E.M. Developing a conceptual framework for the co-operative and mutual enterprise business model. J. Manag. Organ. 2018, 24, 551-581. [CrossRef]

43. Forman, J.B.; Sabin, M.J. Tontine Pensions: A Solution to The Chronic Underfunding of Traditional Pension Plans. SPIS Treści-Contents 2014, 55.

44. Mensah, E.R.; Karantininis, K.; Adégbidi, A.; Okello, J.J. Determinants of commitment to agricultural cooperatives: cashew nuts farmers in Benin. In Proceedings of the International Association of Agricultural Economists Triennial Conference, Foz do Iguaçu, Brazil, 18-24 August 2012.

45. Arouna, A. Assessing the Impact of Collective Marketing of Paddy Rice in Innovation Platforms by Smallholder Producers in Benin. In Rice Crop-Current Developments; IntechOpen: London, UK, 2018.

46. Staal, S.; Delgado, C.; Nicholson, C. Smallholder dairying under transactions costs in East Africa. World Dev. 1997, 25, 779-794. [CrossRef]

47. Devaux, A.; Horton, D.; Velasco, C.; Thiele, G.; López, G.; Bernet, T.; Reinoso, I.; Ordinola, M. Collective action for market chain innovation in the Andes. Food Policy 2009, 34, 31-38. [CrossRef]

48. Markelova, H.; Meinzen-Dick, R.; Hellin, J.; Dohrn, S. Collective action for smallholder market access. Food Policy 2009, 34, 1-7. [CrossRef]

49. Hellin, J.; Lundy, M.; Meijer, M. Farmer organization, collective action and market access in Meso-America. Food Policy 2009, 34, 16-22. [CrossRef]

50. Recanati, F.; Maughan, C.; Pedrotti, M.; Dembska, K.; Antonelli, M. Assessing the role of CAP for more sustainable and healthier food systems in Europe: A literature review. Sci. Total Environ. 2018, 653, 908-919. [CrossRef] 
51. Thaba, K.; Anim, F.; Tshikororo, M. Analysis of Factors Affecting Proper Functioning of Smallholder Agricultural Cooperatives in the Limpopo Province of South Africa. J. Human Ecol. 2016, 54, $150-157$. [CrossRef]

52. Devlin, S.; Wheatley, H. Agricultural Subsidies in the UK after Brexit: A Progressive Solution; A report written by the New Economics Foundation and commissioned by Global Justice Now; New Economics Foundation: London, UK, 2017. article distributed under the terms and conditions of the Creative Commons Attribution (CC BY) license (http://creativecommons.org/licenses/by/4.0/). 